821.163.41.09-1 Пајић П. https://doi.org/10.18485/kij.2019.66.1.7

СНЕЖАНА С. БАШЧАРЕВИТ *

Универзитет у Косовској Митровици

Учитељски факултет у Лепосавићу
Оригинални научни рад

Примљен: 24. 02. 2019.

Прихваћен: 24. 04. 2019.

\title{
РОДОљУБИВИ ИМПУЛС У ПОЕЗИЈИ ПЕТРА ПАЈИЋА
}

\begin{abstract}
Положај песничког опуса Петра Пајића у српској књижевности је специфичан. Он је своју поезију вољно склонио од динамичне песничке сцене. Пајић се само повремено оглашавао новим песмама и збиркама, што указује на стил његовог књижевног живота, а не на књижевну вредност поезије. Иако није показивао изразиту амбицију да се намеће и често појављује, његове песме сведоче о постојаности и верности песничком позиву. Упркос томе, он је песник чије су песме ушле у народ и једнако је препознатљив како својим именом, тако и насловима својих песама, односно наслови његових песама постали су његово друго име. Сматрајући да је случај Петра Пајића у контексту српске савремене поезије још увек недовољно расветљен, требало би превредновати његову поезију. Овај рад има за циљ да укаже на родољубиви импулс у Пајићевој поезији. Његове песме поседују следеће идејне садржаје: историјске, филозофске и етичке. Стога је истраживање применом аналитичо-синтетичке методе нужно. Пајићеве родољубиве песме говоре о српском менталитету и погубној историји у гротескним сликама, на сатиричан начин. Извешћемо закључак да се Пајићеве родољубиве песме срећу са историјом и да се порекло наше несреће налази у наслеђу народног ирационалног, каиновског комплекса.
\end{abstract}

Кључне речи: П. Пајић, поезија, родољубље, Србија, стварност.

Дух родољубља је код нас присутан у начину живљења и поимања света. Он није толико транспарентан нити наметљив, али се једнако обнавља и евоцира у уметности, а посебно у књижевности. Мотив родољубља као и његово касније ширење и духовно отелотворење манифестовало се на непоновљив начин код Светог Саве и бројних наших средњовековних писаца. Он није мимоишао ни изразите модернисте двадесетог века, као што су М. Ракић, А. Шантић, Ј. Дучић, С. Пандуровић, В. П. Дис, В. Рајић, М. Бојић. Мотив Србије, у свом вишедимензионалном облику, постигао је еманципацију у оквиру послератне модерне поезије, од Попиних продора у језгро наше древности и Павловићеве инспирације 
средњовековљем, Миљковићевих епских и фолклорних симболичких упоришта, драматичне трансисторијске визије Ивана В. Лалића - до завичајних предела у поезији Бранка В. Радичевића и Љубомира Симовића.

Овај рад разматра родољубиву поезију Петра Пајића, оцењујући да је припадао кругу песника који су сигурно закорачили у српску поезију, користећи мотиве родољубља као везивну нит између прошлости и садашњости. Шта је Србија значила за Петра Пајића? Она је за њега представљала певање и живљење бола, јер је песник рођењем и животом дубоко судбински везан за родно тле. Наша пажња у овом раду биће усмерена ка откривању Пајићевог нацрта за симбиозу српског тла и књижевности. У његовој родољубивој лирици до изражаја долази осећање припадности националној заједници, земљи, крају, осећање за социјалну правду, за хумане идеале једнакости и братства међу људима, за достојанство човека.

Положај песничког опуса Петра Пајића у српској књижевности је специфичан. Овај песник је своју поезију вољно склонио од динамичне песничке сцене. Да се Пајић само повремено оглашавао новим песмама, збиркама и радовима из области сатире, јесте чињеница књижевног живота, а не оцена књижевне вредности. Иако није показивао изразиту амбицију да се намеће и другима досађује честим појављивањем, његове песме, ипак, сведоче о постојаности и верности песничком позиву. Веран захтеву неосимболиста да озбиљно служи речима - није за пола века свога певања одвише ни написао, што је међу убедљивим доказима одговорне службе, јер се у поезији продуктивност не одмерава бројем песама већ њиховим квалитетом. Пајићеве спорадичне лирске новости праћене су од стране одређеног броја књижевних критичара. Они су његов опус ставили на високо место, али то није довољно. Случај Петра Пајића у контексту српске савремене поезије још увек је недовољно расветљен.

Међу најзначајнијим српским савременим песницима скоро да нема ниједног који није написао један или више програмско-манифестативних текстова. Петар Пајић, међутим, није творац ниједног поетског манифеста, нити пак аутопоетичког критичког текста. Ово, међутим, не значи да не припада низу значајних српских савремених стваралаца. Напротив. Својим невеликим песничким опусом оставио је траг у историји српског песништва на специфичан начин. У том поетичком контексту требало би превредновати његов књижевни опус, а нарочито његову поезију.

Пајићева поезија испуњена је ненаметљивим, али јасно формулисаним рефлексијама, које, доведене у везу, откривају пажљиво разрађен систем идеја прикладних за разноврсна испитивања (филозофска, психолошка, етичка, естетичка, историјска, социолошка). Естетичари би, узимајући у обзир многе изванредне фрагменте о поезији и песницима, у интервјуима који су вођени са њим, могли да пронађу готово све кључне поставке његове поетике. У интервјуима, које је давао за листове Политика и Вечерње новости, осећајући да мора изразити свој стваралачки немир и саопштити сазнања до којих је дошао трагајући за магичном формулом своје поезије, Петар Пајић је проговорио на искрен начин о 
етичким и естетичким темама, постављајући, истовремено, неколико основних начела на којима је изградио своје дело и која су од самог почетка била у самом средишту његових стваралачких интересовања. Разговори који су са њим вођени садржали су елементе античких филозофских дијалошких трактата и особине чисте уметничке поезије, у којима два сабеседника воде наоко неважан, угодан разговор, који, неприметно, решава по једну загонетку и отвара врата ка истинама. Петар Пајић је у овим разговорима свакој мисли и сазнању дао уверљивост и тежину. Познавалац Пајићеве поезије у појединим стиховима може да препозна ставове које је песник изнео у интервјуима. Пајић је у својим поетичким начелима афирмисао непоколебљиву веру у живот поезије, која се упркос свим недаћама и тегобама песничког битисања јавља као основна, битна карактеристика културе. На ову тему у интервјуу датом за дневни лист Политика изјавио је: „Уметничко дело је духовна творевина и оно једино може бити бесмртно” (Радисављевић 2010: 10). У различитим стваралачким фазама он је поетичке ставове износио на експлицитан начин путем поетичких исказа, а на имлицитан путем поетичких фигура. Ова два начина исказивања поетичких ставова у књижевном делу заједно чине аутопоетику једног писца (Перишић 2005: 615). Ради боље илустрације наводимо његов поетички исказ о родољубивој поезији:

„Највећи српски песници писали су родољубиве стихове. Међу њима, истичу се жене: Јефимија, Милица, Десанка. У временима страдања и жртвовања српског народа певало се о томе. Не мислим да су године у којима живимо лакше и боље, али, званично, родољубље се сасвим другачије схвата. Јефимију, Милицу и Десанку, замениле су 'жене у црном'; да је Ђура Јакшић жив, због стихова у којима позива 'Падајте браћо' и 'Бацајте сами у огањ децу', или због оних које је написао о 'тиранки Европи' - био би сигурно у Хагу. Његош је већ, као што знамо, проглашаван за геноцидног песника, а песникиња 'Крваве бајке' за опасну националисткињу. Песнике родољубивих стихова прати променљива судбина: од слављења до хапшења.

Сада, у времену глобализма, код нас није у званичној моди родољубива поезија. Модерно је да се буде против себе. Родољубље је, за многе, фолклор и сметња да се буде Европејац" (Хамовић 2011: 213).

У разговору са Десанком Максимовић, вођеном 1984. године, а чију је награду понео 2014. године, Пајић бележи одговор своје земљакиње на питање откуд потиче родољубиви импулс у њеној поезији: „Родољубиво осећање рађа се из осећања великог националног пораза. Тај стид од пораза за који ниси крив, тај велики бол који су сви осећали, пробудио је у мени родољубива осећања" (Пајић 2007: 44).

Ове Десанкине речи можемо сматрати и једним од начела Пајићеве поетике. Награду је добио, јер обоје имају идентичну песничку стазу која је, пре свега, родољубива, национално обојена. То је српска стаза.

Његова поезија своје садржине крије дубоко у себи, испод смирене, уздржане и отмене спољне једноставности. Знајући да и најдубљу филозофску мисао можемо изразити песнички, Пајић је истовремено и филозоф и песник, који на 
превасходно уметнички начин излаже начела своје поетике, у којој се налази одговор на свако питање што га поставља, одгонетка за све што се у њој скрива и прави кључ за њено разумевање, јер смисао поезије није у томе да сопственим, оригиналним сликама и фигурама копира свет и постојање, него је њен смисао у томе да проникне у изворни смисао света и постојања (Фридрих 2003: 69).

У средишту Пајићевог родољубивог песничког израза јесте присна слика кроз време намучене отаџбине. Он је 2009. године добио награду „Одзиви Филипу Вишњићу”, коју додељује Задужбинарско друштво „Први устанак” за родољубиву поезију, односно за транспарентни израз ововременог родољубља, а 2010. године „Жичку хрисовуљу” за дубински песнички портрет Србије предачке и савремене. Пајић је песник чије су песме ушле у народ и једнако је препознатљив како својим именом, тако и насловима својих песама, односно, наслови његових песама постали су његово друго име.

Тему отаџбине он је најавио кроз лирску тематизацију свога оца. Песма у прози Лице мога оц̧а заметак је Пајићевог отаџбинског певања. Подсетимо се њеног завршетка:

„Било је чисто, у миру и његовој дубини могао сам видети све крваве злочине који су почињени. Хиљаду заклане деце лежало је у очевој руци. Свет се превртао у јаду. Отац висок и прав личио је на саму смрт. Никада нисам сазнао на шта ме је подсећало то лице. Да ли на пораз или на празник. Лице мога оца. Лице мога оца. Његову трагедију понео сам ја у живот" (Пајић 2004: 81).

У застрашујућем виђењу очевог лица огледа се сав удес народа којем припада. Отац постаје оличење отаџбине. Недоумица између пораза и празника даје завршници ове песме кључну семантичку двосмерност, или дволикост, отвара врата парадоксалном смисаоном исходу, као природном разјашњењу.

У песми Опело за Луку Пајића још се одређеније изражава посредничка улога умрлог родитеља између личног и општег искуства:

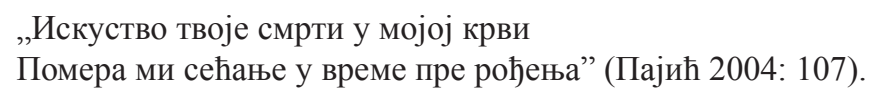

Чије је време пре рођења ако не предачко, а актуелно у часу када се сопствени отац прикључује сакралној заједници отаца?

Песмама о Србији Петар Пајић се исказао као стваралац потпуне отворености према животу и стварности. Он је велику трагедију и национални погром транспоновао у књижевно дело. У време велике етичке депресије и расипа, с једне стране, и етничке угрожености сопственог народа, с друге стране, Пајић управо у песништву налази упориште за избављење из мрака. Када је реч о стваралачком поступку и односу према стварности, он не избегава тешке садржаје живота. У истој равни су Србија, завичај и историја. Чак и када његове песме каткад звуче познато, песник уме да направи обрт, што његовој лирској мелодији даје пуну звуковну и естетску заснованост и универзално значење. Његова поезија је и молитва и клетва. Уме да буде меланхолична и до бола реалистична, готово документарна, што је чини тематски сложеном и идејно асоцијативном. 
Петар Пајић је дубоко преживљавао историјске ломове и својом имагинацијом претварао их у чисту поезију. Отуда су у његовом делу остварене моћне синтезе историје и поезије. Све његове песме за подстицај имају дубинске историјске потресе. Рат и огромни покрети маса подстакли су га да се окрене актуелним догађајима. Пајић је у експлицитним исказима често истицао да сви догађаји, ма како они били потресни и значајни, временом одлазе у заборав. По његовом мишљењу, историјске чињенице постајући уметничке, отржу се забораву и трајно живе у свести читалаца уметничког дела.

Тематски посматрано, он је покушао да у својим песмама представи подручје Србије и живот у њој. Оно што му је било најбитније јесте да песме буду прихватљиве за све који ту живе. Повезујући Пајићеву експлицитну и имплицитну поетику можемо закључити да је сударање литературе и живота у његовом стваралаштву очигледно присутно. Већ смо указали да је присуство завичајних мотива битна компонента поезије овог песника. Овде превасходно имамо у виду тему која је подједнако историјска и савремена, уметничку баштину која чини темеље српског духовног и националног идентитета. А, ништа теже него носити свој идентитет, написао је у својим записима Иво Андрић. Да би изразио све то, Петар Пајић је морао да има велико поверење у песничку реч, у њену моћ, и да новом „читању” историје и традиције приђе на аутентичан начин, не понављајући моделе традиционалних песничких поетика. Следећи стихови песме Буквар земље указују на значење заштитног, уточишног простора, као посебно издвојеног аспекта отаџбине:

„Све је код нас спремно да нас брани и сачува.
И наш говор и наше ћутање
и наши предели и наша имена” (Пајић 2004: 99).

У песми Наша кућа у планини слика дома пренесена је на саму Србију, на границу између опстанка и нестанка, а материнско начело јавља се у митским димензијама и претворено је у чудесну представу:

\footnotetext{
„Уместо лампе у њој звезда једна гори

и мајка наша, видећеш, блага старица седи, лако ћеш познати нашу кућу и по томе што се ноћу види а дању је нема, дању је шума или брдо" (Пајић 2004: 100).
}

Глава куће јесте отац, који је спреман да погине зарад земље, а живот одржава жена, отеловљена родна земља. Пајићева песма Земља, у немуштој и силовитој динамици животног циклуса, обликује лик древне мајке хранитељке и сахранитељке:

„Куцају дамари земље, грмљавина дубока, земља вари живот који да̂ и прогута, снажна и сита и обла око бока, земља растеже живце кроз нове лозе крајпута" (Пајић 2004: 94). 
Пајићева поетика поезију види и као сведочанство, а песника као сведока. То је још једна суштинска одредница књижевног стваралаштва овог песника. Његово сведочење о прошлости и садашњости у својеврсном су паралелизму, сложеном међусобном односу и преплитању. Ниједна уметност не бави се толико феноменом времена као књижевност, посебно поезија: било да трага за оним што је изгубљено или за оним што је актуелно (Ћулавкова 2001: 105).

Сећање на прошлост преображава се у пев о садашњости, као у песми $C p$ бија. Пајићева Србија, у себи противречна, дата је кроз сведену гротескну визију, тамног оргијастичког пијанства и самозаборава, превласти подземних, хтонских порива, па и карневализоване каиновско-авељевске приче. Песник нам приказује располућену историју, према моделу сукоба вођа двају српских устанака:

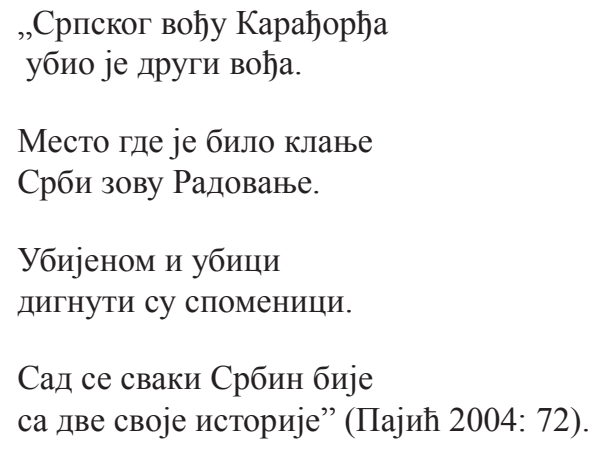

Песма се завршава инверзијом, небесна и земна Србија замењују места. У непосејаном јесенском црном тлу пламињају душе многих Милица и Милована, одоздо звоне грачаничка звона. Србија се сели са лица земље:

„Под земљом сам ти видео лице,

Србијо, земљо небеснице” (Пајић 2004: 77).

Поводом поезије Петра Пајића увек се говори о искрености, што је синоним за аутентичност и лирски таленат. Стихови попут разглашених:

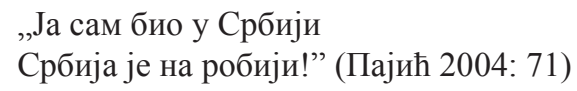

или:

$$
\begin{aligned}
& \text { „Срби седе у кафани } \\
& \text { што пијани, што поклани” (Пајић 2004: 71) }
\end{aligned}
$$

утицали су да га многи критичари доживе и као песника домољубних парола, али и као афористичара. О том односу јавности сведочи и неколико награда за сатиру, које је Пајић добио („Награда Типар” за сатиричара године, „Награда Радоје Домановић” за укупан допринос српској књижевној сатири).

У песми Црно поље песник посеже за сликом Србије редукованом на апстраховани симболички простор испрва нераспознатљивог поља, притиснутог непознатом сенком што пречи сваки облик живота и делања - да би поентирао разорним сазнањем: 
„Поље је наше, сине,

и сенка је наша на њему” (Пајић 2004: 85).

Лирски субјект у његовим песмама носи велику унутрашњу драму, било да је заточеник у свету или је сасвим ослобођен животних норми и оквира. Људи јесу ковачи сопствене среће и несреће, али о многим стварима, често и оним суштинским, одлучују други, затим околности, непредвидљиве случајности, више но што то на први поглед изгледа. Српска драма је у средишту читавог књижевног стваралаштва и ангажмана Петра Пајића. Она му је дала суштинска својства и идентитет. Песме су му и документована стварност о страдању, избеглиштву и изгубљеном завичају. Када је хиљаде и хиљаде невољника прокаженог народа прогнано у Србију, Пајић је одговорио не као бучни трибун, него као сабрат што има очи да види и прозире у дубину догађаја, у изврсној, елегичној песми Пада снег:

„Пада снег годинама без шума.

На Србију, на бедни људски збег.

Нема нигде правца, нигде друма.

Пада снег, пада снег, пада снег” (Пајић 2004: 114).

Његова родољубива поезија везана је за биће српског народа, за све што чини традицију и баштину, за прогонство као усуд.

Питање родољубиве поезије је и питање опстанка српског народа и бол за српском земљом. Код Пајића Србија избија као митопоетска тема. Српски бол тражио је песника који ће у крвотоку своје поезије носити архетип античке трагедије, а у срцу своје песме отаџбински завет. Он је у својим песмама приказао драму српског страдања, овоземаљски и космички бол виђеног и неслућеног, где се реално ближи иреалном и обрнуто, али и кондензовану човекову зебњу пред српским и свеопштим удесом. То је поезија која у најширем смислу значи ламент над Србијом и јавља се као надмоћ у односу на ужас, уверавајући нас да је песник дорастао једном тако великом животном и литерарном чину. Метафизичка стрепња и студ не затварају ову поезију како би је заробиле и обеснажиле, већ враћају живот том народу, уливајући му наду и стоицизам.

Родољубива поезија Петра Пајића представља вертикалу српског страдања, али и трајања и отпора, којом је песник подигао вечни споменик српским страдалницима и српској земљи. На нашем тлу не страда само човек, Србин, него и његова културна и материјална добра, зато су многе песме духовног садржаја, у чијем је средишту богата слојевитост, поетска отменост и суптилан израз. Петар Пајић је песник са јасним ставом према историјским и актуелним догађајима. Огледало националне историје - огледало је песникове душе. Са јаким и јасно исказаним патриотским осећањима поклоничке љубави и дивљења према духовном наслеђу и историјском предању о осведоченом јунаштву и херојској истрајности предака, у својим песмама он је исписао странице које, почивајући на трагичном али светом историјском искуству, исијавају безрезервном вером у 
ренесансну будућност и у њима је човек, тако типични пајићевски лирски јунак, онај који тежину патњи и величину и славу победа износи на својим плећима.

Узев у целини, српска родољубива поезија је дубоко прожета и условљена националном историјом и актуелном политиком, тако да се једним својим делом природно прелива у правцу критичког односа. У томе погледу је нарочито драгоцено песништво Петра Пајића, које се преображава у стишану патриотску оданост и понос над дивним пределима српства, али и у меланхоличну сумњу да је можда славна прошлост неповратно минула. Песник пева из најличније позиције о најновијем националном удесу српског народа, тј. о његовој ововременој унесрећености. Он опева текућу српску удесну драму (и појединачну и колективну), теготу и мучнину живљења на рођеној земљи. Родољубива поезија Петра Пајића је испевана пунокрвно, звонко и јасно. Њена блистава енергија исијава из њеног тона, из чистог лирског гласа који буди неумрла сећања и крепи душу благошћу и вером у постојаност победа: радних, ратних, духовних. Њена вера у национални опстанак и ренесансу расте из песникове свести о трагичној историјској судбини народа из чијег духа се издигла и чијој благодатнијој будућности стреми.

На крају закључујемо да је Петар Пајић свој песнички флуид, своју лирику и лични доживљај претворио у велику слику, у општу појаву и широко кретање, али да ово певање има и другу релацију: то је унутрашње усмерење где је он опште претворио у лирско. То је његова двосмерна молитва за српски усуд. Пајић је трагедију српског поднебља пратио мотивима родољубља, завичајном интонацијом, као најприкладнијим метафоријским смислом. Његову родољубиву поезију можемо окарактерисати као дневник дубоког и личног доживљаја који се односи на све Србе. Пајић исказује суштинско незадовољство лирског субјекта спољашњим светом, као и отпор према отуђеној стварности и профанисаном друштвеном животу. Једна од најбитнијих, а вероватно најзначајнијих линија његове поезије чине песме о Србији, њеној традицији, култури и менталитету. У његовим родољубиво-меланхоличним или сатиричним песмама проговорила су различита лица и времена Србије, у широком распону од породичних до националних. Песник не скрива свој став да нисмо способни да учимо из онога што нам се дешавало, па зато никаква озбиљна порука нема сврху. Петар Пајић је опевао и промислио историјски удес српског народа. Он је у Србији видео стравичне призоре библијских димензија, митске слике препуне неспокоја, владарске обрачуне, разједињеност и неслогу српског народа, братоубилаштво, ратна разарања и погибије невиних. Петар Пајић је српску стварност претворио у метафору, у симбол, у стих и својом поезијом обележио савремену српску стварност, а печат јој је дао родољубиви импулс. 


\section{ЛИТЕРАТУРА}

Бахтин 1991: М. Бахтин, Аутор и јунак у естетској активности, Нови Сад: Светови.

Деретић 1997: Ј. Деретић, Поетика српске књижевности, Београд: Филип Вишњић.

Ђорђевић 2013: Б. Ђорђевић, „Где су биле кафане сада царују банке”, Beчерње новости, 05. 10. 2013, 7.

Ђурић 1965: В. Ђурић, Лирика, Београд: Завод за уџбенике и наставна средства.

Еко 1965: У. Еко, Отворено дјело, Сарајево: Веселин Маслеша.

Еко 1995: У. Еко, Симбол, Београд: Народна књига.

Јовичић 1973: В. Јовичић, „О родољубивом лирском надахнућу”, Къижевна историја, 19, 63-75.

Лотман 1976: Ј. Лотман, Структура уметничког текста, Београд: Нолит.

Пајић 2004: П. Пајић, Најлепше песме Петра Пајића, Београд: Просвета.

Пајић 2007: П. Пајић, Нешто као, Бања Лука: Арт принт.

Пајић 2015: П. Пајић, Поезија, Београд: Задужбина „Десанка Максимовић” - Народна библиотека Србије.

Палавестра 1995: П. Палавестра, Историја модерне српске књижевности. Златно доба 1892-1918, Београд: Српска књижевна задруга.

Перишић 2005: И. Перишић, „Прилог за дефиницију термина аутопоетика", Кьижевна историја, 127, 615-626.

Радисављевић 2010: 3. Радисављевић, „Поезији није одзвонило”, Полити$\kappa a, 19.08 .2010,10$.

Саболчи 1997: М. Саболчи, Авангарда и неоавангарда, Београд: Народна књига.

Скерлић 1908: Ј. Скерлић, „Обнова наше родољубиве поезије”, Српски књижевни гласник, 6, 38-46.

Солар 1971: М. Солар, Питања поетике, Загреб: Школска књига.

Станишић 2016: М. Станишић (ур.), Поезија Петра Пајића: зборник радова, Београд: Задужбина „Десанка Максимовић” - Народна библиотека Србије.

Станковић 2005: Д. Станковић, „Књиге у сенци”, Вечерње новости, 03. 12. 2005, 9 .

Ћулавкова 2001: К. Ћулавкова, Поетика лирике, Београд: Народна књига-Алфа.

Фридрих 2003: Х. Фридрих, Структура модерне лирике: од средине 19. до средине 20. века, Нови Сад: Светови.

Хамовић 2011: Д. Хамовић (ур.), Петар Пајић песник, Краљево: Народна библиотека „Стефан Првовенчани”.

Човић 1989: Б. Човић, Поетска слика, Нови Сад: ИСКЈ.

Шутић 1987: М. Шутић, Лирско и етика, Београд: Институт за књижевност и уметност. 
Snežana S. Baščarević

\title{
RELATIVATED IMPULS IN THE POETRY OF PETAR PAJIĆ
}

\author{
Summary
}

The position of the poetic opus of Petar Pajic in Serbian literature is specific. He willingly withdrew his poetry from a dynamic poetic scene. Pajić only occasionally advertised with new songs and collections, indicating the style of his literary life, not the literary value of poetry. Although he did not show a strong ambition to impose himself and often appears, his poems testify to perseverance and loyalty to the poetic appeal. In spite of this, he is a poet whose songs entered the people and is equally recognizable by his name and by the title of his own songs and the titles of his songs. Considering that the case of Petar Pajic in the context of Serbian contemporary poetry is still insufficiently illuminated, we revised his poetry. His aim was to point out a patriotic impulse in Pajić's poetry. His poems have the following conceptual contents: historical, philosophical and ethical. Therefore, research using analytical-synthetic methods was necessary. Pajić's patriotic songs speak of Serbian mentality and disastrous history in grotesque paintings, in a satirical way. We have come to the conclusion that Pajic's patriotic songs meet with history and that the origin of our misfortunes lies in the heritage of the national irrational, Kain complex.

Key words: P. Pajić, poetry, patriotism, Serbia, reality. 